\title{
Ebeveynleşme ile Depresyon, Kaygı, Stres Arasındaki İlişkide Benliğin Ayrımlaşmasının Aracı Rolü
}

\author{
DOI: $10.26466 /$ opus.883816 \\ * \\ $\underline{\text { Ali Karataș }}$ * Bülent Gündüz ** \\ * Rehber Öğretmen, MEB, Hatay/Türkiye \\ E-Posta: alikaratas396@gmail.com \\ ORCID: $0000-0002-8155-638 \mathrm{X}$ \\ ** Prof. Dr, Mersin Üniversitesi, Eğitim Fakültesi, Mersin/Türkiye \\ E-Posta: $\underline{\text { bgunduz27@gmail.com }}$ \\ ORCID: $\underline{0000-0002-8451-816 \mathrm{X}}$
}

\begin{abstract}
$\ddot{O ̈ z}$
$\mathrm{Bu}$ araştırmanın amacl, ebeveynleşme ile depresyon, kaygl, stress arasındaki ilişkide benlik ayrımlaşmasının aracı rolünün incelenmesidir. Bu amaç doğrultusunda 768'I kadın, 429'u erkek olmak üzere toplam 1197 genç yetişkin bireyden veri toplanmıştır. Araştırmanın verileri ebeveynleşme envanteri, depresyon, anksiyete, stress ölçeği ve benlik ayrımlaşması ölçeği kullanılarak toplanmıştır. Araştırmadan elde edilen veriler arasındaki ilişkiler Pearson Momentler Çarpımı Korelasyon Katsayısı kullanılarak incelenmiştir. Aracıllk rolü analizleri regresyon analizi vasıtasıyla yapılmıştır. Bununla birlikte aracıllk etkisinin istatistiksel olarak anlamlılı̆̆ın belirlemek amacıyla Sobel Z testi kullanılmıştır. Araştırmadan elde edilen bulgulara göre benlik ayrımlaşmasının ebeveyn odakl ebeveynleşme ile depresyon arasındaki ilişkide aracı rolü bulunmazken; ebeveyn odakl ebeveynleşme ile kaygı ve stres arasındaki ilişkide kısmi aracılık rolü olduğu belirlenmiştir. Diğer bir bulgu ise, benlik ayrımlaşmasının kardeş odakl ebeveynleşme ile depresyon ve stres arasindaki ilişkide tam aracı rolü olduğunu göstermektedir. Kardeş odakh ebeveynleşme ile kaygı arasındaki ilişkide ise benlik ayrımlaşmasının kısmi aracılık rolü olduğu gözlenmiştir. Son olarak ebeveynleşmeden algılanan yarar ile depresyon, kaygı ve stres arasındaki ilişkide benlik ayrımlaşmasının kısmi aracı rolü olduğu bulunmuştur.
\end{abstract}

Anahtar Kelimeler: Ebeveynleşme, depresyon, kaygı, stres, benlik ayrımlaşması. 


\title{
The Investigetion of the Mediating Role of Differentiation of Self in Relationship between Parentification and Depression, Anxiety and Stress
}

\begin{abstract}
The aim of this study is to examine the mediating role of self-differentiation in the relationship between parentification and depression, anxiety, and stress. For this purpose, data were collected from a total of 1197 young adults, 768 of whom were women and 429 men. The data of the study were collected using the parentification inventory, depression, anxiety, stress scale, and the differentiation of self scale. Relationships between the data obtained from the research were analyzed by using Pearson Product Moment Correlation. Mediation analyzes were carried out by regression analysis. The Sobel $\mathrm{Z}$ test was used to determine the statistical significance of the mediation effect. According to the findings of the study, there is no mediating role of self-differentiation in the relationship between parent-focused parentification and depression; a partial mediating role was determined in the relationship between parent-focused parentification and anxiety and stress. Another finding shows that self-differentiation has complete mediating role in the relationship between sibling focused parentification and depression and stress. In the relationship between sibling focused parentification and anxiety, it was observed that self differentiation has a partial mediating role. Finally, it was found that self-differentiation had partial mediating role in the relationship between perceived benefit of parentalification and depression, anxiety, and stress.
\end{abstract}

Key Words : Parentification, depression, anxiety, stress, differentiation of self. 


\section{Giriş}

Sistem teorisine göre aile, yalnızca bireylerin bir araya gelerek oluşturduğu bir yapı değil parçaların bir araya gelmesinden daha anlamlı bir bütündür. Bu teoriye göre ailenin bütün parçaları birbiri ile etkileşim halinde olmakla birlikte, aileyi oluşturan bireylerin birbirleri ile ilişkileri de kendilerine özgü bir örüntü sergiler (Özabacı ve Erkan, 2017). Bireyler arasındaki bu özgün örüntüler, aile üyeleri arasındaki etkileşim ve iletişim kalıpları ile aile yapısı ve organizasyonu hakkında ipuçları taşır (Becvar ve Becvar, 2009). Alt sistemler kısaca bütünü oluşturan daha küçük parçalardır. Ailede her birey farklı güç, hiyerarşi ve beceri edindiği alt sistemleri oluşturur. Başlıca alt sistemler eş, ebeveyn ve kardeş alt sistemleridir ve bu alt sistemler en iyi şekilde kurallar ve sınırlarla tanımlanırlar (Minuchin ve Fishman, 1999). Sinırlar, bir alt sisteme kimin nasıl katılacağını belirleyen kurallardır. Diğer bir ifadeyle, aile içerisinde alt sistemlerin ve bireylerin birbirleri ile nasıl ve ne kadar etkileşime gireceğini düzenleyen görünmez çizgilerdir. (Minuchin, 1974).

Aileler kültürel yapıları ve etnik geçmişleri nedeniyle farklılık gösterseler de Parke ve Buriel (1998), sağlıklı bir aile için tutarlı, işbirliğine dayalı bir ebeveyn alt sisteminin kritik olduğunu belirtir. Bu ebeveyn alt sistemi, çocuğun beslenmesi, yönlendirilmesi ve kontrolü için sorumluluk alarak çocuk üzerinde otorite durumunda olmalıdır (Madden-Derdich, UlloaEstrada, Updegraff ve Leonard, 2002). Ebeveyn alt sisteminin merkezde, s1nırlarının belirgin ve esnek olması ailenin sağlıklı işlev göstermesi için gereklidir (Grief, 1996). Ailelerde, ebeveynleri çocuklarının üzerinde bir otorite konumuna yerleştiren güç hiyerarşisi bozulduğunda, çocuğun eş ve ebeveyn işlevlerini üstlenmesine yol açan sorunların doğduğu gözlenmiştir. Ebeveyn ve çocuk arasındaki sınır ihlal edildiğinde, çocuğun aile sistemi içindeki rolü belirsizleşir, çocuğun gelişimsel durumuyla tutarsız olan görev ve sorumlulukları üstlendiği bir durum olan ebeveyn çocuk (Madden-Derdich vd., 2002; Minuchin, 1974) ya da ebeveynleşme görülebilir (Boszormenyi-Nagy ve Spark, 1973).

Ebeveynleşme çocuğun ebeveynleri ya da aile üyelerinden birinin bakım rolünü üstlendiği nesiller arası rol dönüşümü olarak da tanımlanmaktadır (Khafi, Yates ve Luthar, 2014). Araştırmalar bakım veren kişi rolünde olmanın genellikle artan depresyon, stres ve anksiyete 
ile ilişkili olduğunu göstermiştir (Majestic ve Eddington, 2019). Yapılan çalışmalarda ebeveynleşmenin depresyon, kaygı, stres, düşmanlık, somatizasyon, psikotizm gibi psikolojik belirtilerle pozitif yönlü ve anlamlı ilişkiler gösterdiği saptanmıştır (Derikozis ve Wingsiong, 2017; Köyden ve Uluç, 2018; Arellano, Mier-Chairez, Tomek ve Hooper, 2018).

Aile alt sistemleri arasında belirgin sinırların eksik olması; bireylerin benlik ayrımlaşmasının yeterince gerçekleşmemesi olarak ifade edilebilir. Bu durum aile sistemi içerisinde dengenin sürdürülmesi için kişisel tercihlerin bir kenara bırakılması ve psikolojik sıkıntılarla yakından ilişkili bulunmuştur (Brown, 1999). Benliğin ayrımlaşması, bireylerin duygu ve düşüncelerini birbirinden ayırması; bunun yanı sıra, bireyin kendini köken ailesinden duygusal ve bilişsel olarak ayrımlaştırması olarak tanımlanmaktadır. Genel olarak ailede sağlıklı işleyiş özellikle de sağlıklı ilişkisel işleyiş kendini ayrımlaşma derecesi ile ilişkilidir (Bowen, 1978). Yapılan çalışmalar benlik ayrımlaşması düşük olan bireylerin daha yüksek düzeyde depresyon (Hooper ve DePuy, 2010; Lee ve Kim, 2019; Rodriguez-Gonzalez vd., 2018), kaygı ve stress (Hanımoğlu ve Akbaş, 2018; Polat ve İlhan, 2018) yaşadıklarını göstermektedir.

Ebeveynleşme ve depresyon, kaygı, stres ile ilgili yapılan çalışmalar incelendiğinde benliğin ayrımlaşmasının ebeveynleşen çocukların yaşadıkları bu duygusal güçlükleri nasıl etkilediğinin henüz ele alınmadığı görülmektedir. Araştırma aile içerisinde meydana gelen rol değişimlerinde kendini köken aileden sağlıklı bir şekilde ayrımlaştırabilmek yani bireysellik ve birliktelik arasında bir denge kurmanın bireylerin yaşadıkları psikolojik sıkıntılar üzerinde nasıl bir etkisi olduğunu incelemesi açısından literature yeni bir bakış açısı kazandırmaktadır.

Çocukluk ve ergenlik dönemlerinde de bireylerin yetişkin yaşamına hazırlanması amacıyla çeşitli rol ve görevleri deneyimlemesi çocuğun gelişimi açısından önemlidir. Ancak bu durum her zaman beklenildiği gibi gerçekleşmemekte; çocukların yetiştikleri ailede daha fazla sorumluluk almasını ve rollerini değiştirmesini gerektiren durumlar artmaktadır. Örneğin, ailede sosyo ekonomik durumunun düşük olması, boşanma, kronik rahatsızlıklar, ebeveynlerden birinin şehir dışında çalışması gibi nedenlerden dolayı aile üyelerine ait rol ve sorumlulukların uygun olmayan bir şekilde çocuğa yüklenmesi onun gelişimi üzerinde önemli sonuçlara yol 
açabilmektedir. Böylece çocuğun aşırı düzeyde yetişkin rol ve sorumluluklarını üstlenmesi kendi gelişim görevlerini yerine getirememesine ve çeşitli psikolojik sıkıntılar yaşamasına neden olabilir (Akün, 2017; Hooper, 2017; Zencir, 2018). Ebeveynleşme ve aile sistemindeki sorunlar özellikle de aile de sınırların ihlali ile ilişkili görülmektedir. Bu noktadan hareketle ebeveynleşmiş bireyin aile üyeleri ile bireysellik ve beraberlik arasında bir denge kurabilmesini ifade eden benliğin ayrımlaşmasının ebeveynleşme ile psikolojik sıkıntılar arasındaki ilişkide rolünün incelenmesi önemlidir.

$\mathrm{Bu}$ amaç doğrultusunda aşağıdaki sorulara yanıt aranmıştır:

1. Ebeveyn odaklı ebeveynleşme ile depresyon, kayg1, stres puanları arasındaki ilişkide benliğin ayrımlaşmasının aracı rolü var mıdır?

2. Kardeş odaklı ebeveynleşme ile depresyon, kaygı ve stres puanları arasındaki ilişkide benlik ayrımlaşmasının aracılık rolü var midir?

3. Ebeveynleşmeden algılanan yarar ile depresyon, kaygı ve stres puanları arasındaki ilişkide benliğin ayrımlaşmasının aracı rolü var midir?

\section{Yöntem}

\section{Araştırma Modeli}

Bu çalışmada ebeveynleşme ve depresyon, anksiyete ve stres arasındaki ilişkide benliğin ayrımlaşmasının aracı rolü olup olmadığını belirlemeye yönelik yapılan ilişkisel tarama modelinde bir araştırmadır. İlişkisel tarama yöntemi iki ya da daha fazla değişkenin birlikte değişip değişmediğini saptamaya çalışan, değişkenler birlikte değişiyorsa bu değişimin nasıl olduğunu göstermektedir (Karasar, 2011).

\section{Çalışma Grubu}

$\mathrm{Bu}$ araştırmanın çalışma grubu 2019-2020 eğitim-öğretim döneminde çeşitli üniversitelerdeki 1253 öğrencinin gönüllü katılımı ile oluşturulmuştur. Çalışma grubuna, katılımcılara kolay ve ucuz bir şekilde ulaşmak anlamına gelen uygun örnekleme yöntemiyle ulaşılmıştır (Bayram, 2015). Araştırmaya katılan 56 kişi formu eksik, özensiz doldurma 
gibi farklı sebeplerle çalışma dışında bırakılmıştır. Sonuç olarak araştırma 429’u (\%35,8) erkek ve 768'i (\%64,2) kadın toplam 1197 öğrencinin katılımı ile yürütülmüştür.

\section{Veri Toplama Araçları}

Araştırma kapsamında "Ebeveynleşme Envanteri", "Benliğin Ayrımlaşması Ölçeği”, "Depresyon-Anksiyete-Stres Ölçeği” olmak üzere 3 farklı ölçek kullanılmıştır.

Ebeveynleşme Envateri: Hooper (2009) tarafından geliştirilen ve Türk kültürüne uyarlaması Köyden (2015) tarafından yapılan “Ebeveynleşme Envanteri(EE)" toplam 20 maddeden oluşan 5'li likert tipi derecelendirmenin kullanıldığı bir ölçektir. Ölçek ebeveyn odaklı ebeveynleşme, kardeş odaklı ebeveynleşme ve ebeveynleşmeden algılanan yarar alt boyutlarından oluşmaktadır. Ölçek her bir alt boyut için toplam puan alınarak ayrı ayrı değerlendirilmektedir. Ebeveynleşme envanteri için ölçeğin Cronbach alfa iç tutarlık katsayısı .82 bulunmuş olup bu çalışmada Cronbach alfa iç tutarlık katsayısı .84 olarak hesaplanmıştır.

Depresyon-Anksiyete-Stres Ölçeği:Lovibond ve Lovibond (1995) tarafından tek bir ölçek aracılığıyla bireylerin depresyon, kaygı ve stres düzeylerini belirlemek amacıyla geliştirilmiştir. Türk kültürüne uyarlaması Akın ve Çetin (2007) tarafından yapılan ölçek 42 madde ve 4'lü Likert tipi bir ölçektir. Ölçekte yer alan 14 madde depresyon, 14 madde kaygı, 14 madde stresi ölçmektedir. Ölçekte yer alan her alt boyut ayrı ayrı toplam puan alarak değerlendirilmektedir. Her alt boyuttan alınan puanların yüksekliği depresyon, kaygı ve stresin arttığını göstermektedir. Depresyon, kaygı, stres ölçeği için ölçeğin Cronbach alfa iç tutarlık katsayıları sırasıyla .81, .90, .92 bulunmuş olup bu çalışmada Cronbach alfa iç tutarlık katsayıları sırasıyla .76, .93, .91 olarak hesaplanmıştır.

Benliğin Ayrımlaşması Ölçeği: Benliğin ayrımlaşması ölçeği; Skowron ve Friedlander (1998) tarafından benliğin ayrımlaşma düzeylerini belirlemek için geliştirilmiş daha sonra Skowron ve Schmitt (2003) tarafından revize edilmiştir. Türk kültürüne uyarlaması Işık ve Bulduk, (2015) tarafından 
yapılan ölçek toplam 20 maddeden oluşan $6^{\prime}$ lı likert tipi maddelerden oluşmaktadır. Duygusal Tepkisellik, Ben Pozisyonu Alma, Duygusal Kopma ve Başkalarına Bağımlılık olmak üzere 4 alt boyutu bulunmaktadır. Ölçekten alınan puanların yükselmesi bireyin daha iyi benlik ayrımlaşmasına sahip olduğuna işaret etmektedir. Benliğin ayrımlaşması için ölçeğin Cronbach alfa iç tutarlık katsayısı .81 bulunmuş olup bu çalışmada Cronbach alfa iç tutarlık katsayısı .76 olarak hesaplanmıştır.

\section{Verilerin Analizi}

Araştırma kapsamında ilk olarak değişkenler arasındaki ilişkileri belirleyebilmek amaciyla Pearson Momentler Çarpımı Korelasyon Katsayısı kullanılmıştır. Değişkenler arasında anlamlı ilişkiler bulunmuş daha sonra ise aracılık rolünün incelenmesi amacıyla Baron ve Kenny'nin (1986) varsayımları kullanılmıştır. Bu doğrultuda değişkenlerin aracılık rolünü belirleyebilmek amacıyla çoklu regresyon analizi yapılmıştır.

\section{Bulgular}

Araştırmaya katılanların ebeveynleşme, benlik ayrımlaşması, depresyon, kaygı ve stres puanları arasındaki ilişkilerin belirlenmesi amacıyla Pearson Momentler Çarpımı Korelasyon Katsayısı kullanılmış ve sonuçlar Tablo 1. 'de verilmiştir.

Tablo 1 İncelendiğinde depresyon ile kardeş odaklı ebeveynleşme $(\mathrm{r}=.107 ; \mathrm{p}<.01)$ arasında pozitif yönde; ebeveynleşmeden algılanan yararla arasında negatif yönde $(r=-.248 ; \mathrm{p}<.01)$ anlamlı ilişkiler olduğu görülmektedir. Ayrıca ebeveyn odaklı ebeveynleşme ile depresyon arasındaki ilişki anlamlı bulunmamıştır(r=.049; $\mathrm{p}<.01)$. Kaygı ile ebeveyn odaklı ebeveynleşme $(\mathrm{r}=.119 ; \mathrm{p}<.01)$ ve kardeş odaklı ebeveynleşme $(\mathrm{r}=.188 ; \mathrm{p}<.01)$ arasinda pozitif yönde; ebeveynleşmeden algılanan yararla arasında negatif yönde $(\mathrm{r}=-.168 ; \mathrm{p}<.01)$ anlamlı ilişkiler olduğu görülmektedir. Stres ile ebeveyn odaklı ebeveynleşme $(\mathrm{r}=.100 ; \mathrm{p}<.01)$ ve kardeş odaklı ebeveynleşme $(\mathrm{r}=.136 ; \mathrm{p}<.01)$ arasında pozitif yönde; ebeveynleşmeden algılanan yararla arasında negatif yönde(r=-.155; $\mathrm{p}<.01)$ anlamlı ilişkiler olduğu görülmektedir. 
Tablo 1. Betimsel istatistikler ve değişkenler arası korelasyonlar

\begin{tabular}{llllllll}
\hline Değişkenler & $\mathbf{1}$ & $\mathbf{2}$ & $\mathbf{3}$ & $\mathbf{4}$ & $\mathbf{5}$ & $\mathbf{6}$ & $\mathbf{7}$ \\
\hline 1. EOB & 1 & & & & & & \\
2. KOB & $.524^{* *}$ & 1 & & & & & \\
3. EAY & $.205^{* *}$ & -.023 & 1 & & & & \\
4. BA & $-.072^{*}$ & $-.175^{* *}$ & $.171^{* *}$ & 1 & & & \\
5. Depresyon & .049 & $.107^{* *}$ & $-.248^{* *}$ & $-.483^{* *}$ & 1 & & \\
6. Kayg1 & $.119^{* *}$ & $.188^{* *}$ & $-.168^{* *}$ & $-.520^{* *}$ & $.800^{* *}$ & 1 & $.854^{* *}$ \\
7. Stres & $.100^{* *}$ & $.136^{* *}$ & $-.155^{* *}$ & $-.517^{* *}$ & $.801^{* *}$ & 1 \\
$\quad$ Ss & 7,55 & 3,84 & 4,60 & 12,66 & 11,01 & 10,17 & 10,52 \\
\multicolumn{1}{c}{ Ort } & 24,18 & 10,29 & 21,66 & 78,39 & 14,45 & 15,19 & 18,79 \\
\hline
\end{tabular}

${ }^{*} E O B=E b e v e y n$ Odakl Ebeveynleşme, KOB=Kardeş Odaklı Ebeveynleşme, EAY=Ebeveynleşmeden Algılanan Yarar, BA=Benlik Ayrımlaşması

Diğer taraftan; benlik ayrımlaşması ile depresyon ( $\mathrm{r}=-.483$; $\mathrm{p}<.01)$, kayg1 $(\mathrm{r}=-.520 ; \mathrm{p}<.01)$, stres $(\mathrm{r}=.517 ; \mathrm{p}<.01)$, ebeveyn odaklı ebeveynleşme $(\mathrm{r}=-.072 ; \mathrm{p}<.05)$ ve kardeş odaklı ebeveynleşme $(\mathrm{r}=-.175 ; \mathrm{p}<.01)$ arasında negatif yönde anlamlı ilişkiler bulunmuştur. Benlik ayrımlaşması ile ebeveynleşmeden algılanan yarar $(\mathrm{r}=.247 ; \mathrm{p}<.01)$ arasında ise pozitif yönde anlamlı ilişkiler bulunmuştur.

Ebeveyn odaklı ebeveynleşme ile depresyon, benlik ayrımlaşması arasindaki doğrudan ve dolaylı ilişkiler Şekil-1'de yer almaktadır.

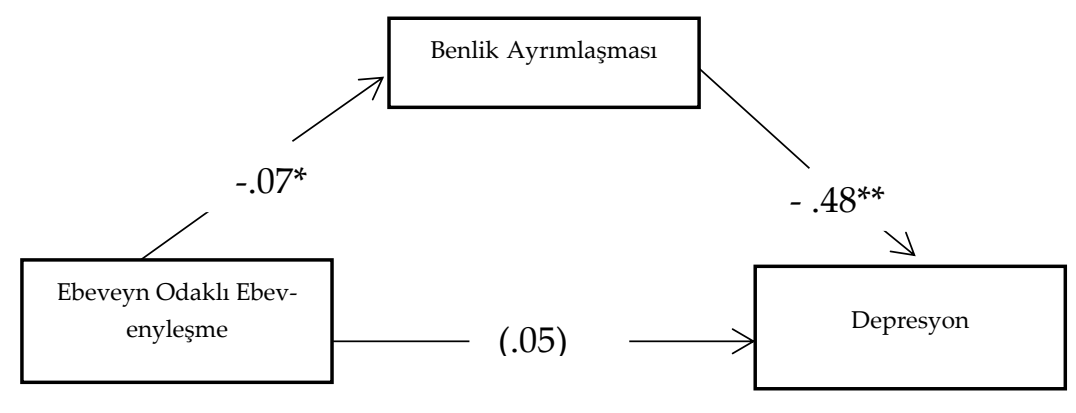

$N=1197,{ }^{* *} p<.01{ }^{*} p<.05$

Şekil 1. Benlik Ayrımlaşmasının Ebeveyn Odaklı Ebeveynleşme ile Depresyon Arasındaki Aracı Rollerine Ait Beta Katsayıları

Şekil 1'de görüldüğü gibi, ebeveyn odaklı ebeveynleşme puanları ile benlik ayrımlaşması $(\beta=-.07, \mathrm{p}<.05)$ ve benlik ayrımlaşması ile depresyon $(\beta=-.48, p<.01)$ arasında anlamlı ilişkiler olduğu belirlenmiştir. Diğer 
taraftan, ebeveyn odaklı ebeveynleşme ve depresyon arasında anlamlı bir ilişki bulunmamıştır ( $\beta=.05, p>$.05). Bu kapsamda ebeveyn odaklı ebeveynleşme ile depresyon arasındaki yol katsayısı istatistiksel olarak anlamsız olduğu için aracılık analizi yapılamamıştır.

Ebeveyn odaklı ebeveynleşme ile kaygı, benlik ayrımlaşması arasındaki doğrudan ve dolaylı ilişkiler Şekil-2'de yer almaktadır.

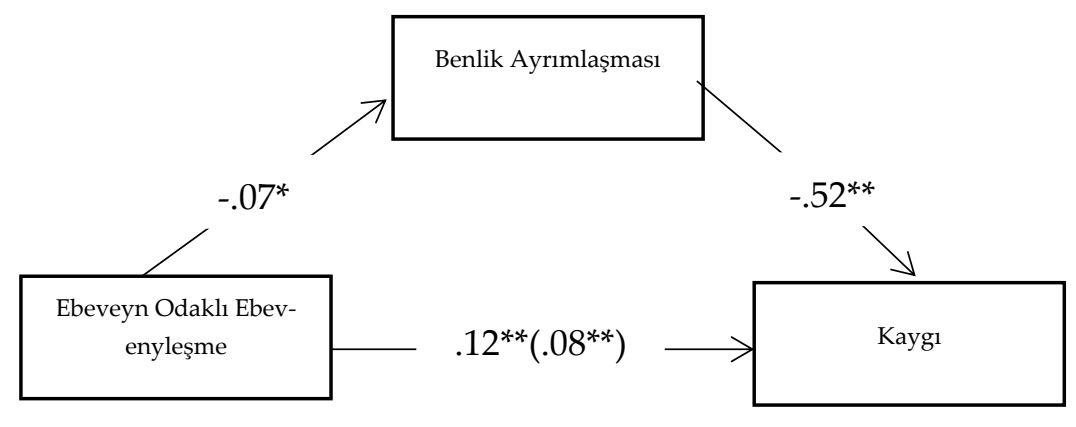

$N=1197,{ }^{* *} p<.01{ }^{*} p<.05$

Şekil 2. Benlik Ayrımlaşmasının Ebeveyn Odaklı Ebeveynleşme ile Kaygı Arasındaki Aracı Rolüne Ait Beta Katsayıları

Şekil 2'de görüldügü gibi, benlik ayrımlaşmasının aracılık rolünün incelenmesi için ilk olarak, ebeveyn odaklı ebeveynleşme ile kaygı arasındaki doğrudan ilişkinin anlamlı olduğu belirlenmiştir $(\beta=.12, \mathrm{p}<.01)$. İkinci aşamada ebeveyn odaklı ebeveynleşme ve benlik ayrımlaşması $(\beta=-.07$, $\mathrm{p}<.05)$, benlik ayrımlaşmasından kaygıya giden yolun anlamlı olduğu görülmektedir $(\beta=-.52, p<.01)$. Son olarak, benlik ayrımlaşmasının aracılık rolü test edilmiş ve ebeveyn odaklı ebeveynleşme ile kaygı arasındaki yol katsayısında 4 puanlık anlamlı düşüş görülmektedir $(\beta=.08, \mathrm{p}<.01)$. Bu kapsamda ebeveyn odaklı ebeveynleşme ile kaygı arasındaki ilişkide benlik ayrımlaşmasının kısmi aracılık rolü üstlendiği belirlenmiştir. Kısmi aracılık etkisinin anlamlılığını değerlendirmek amacıyla Sobel testi yapılmıştır. Sobel testi sonucunda yol analizindeki değişimin anlamlı olduğu görülmüştür (Sobel Z=2.48; $\mathrm{P}<.05$ ).

Ebeveyn odaklı ebeveynleşme ile stres, benlik ayrımlaşması arasındaki doğrudan ve dolaylı ilişkiler Şekil-3'de yer almaktadır. 


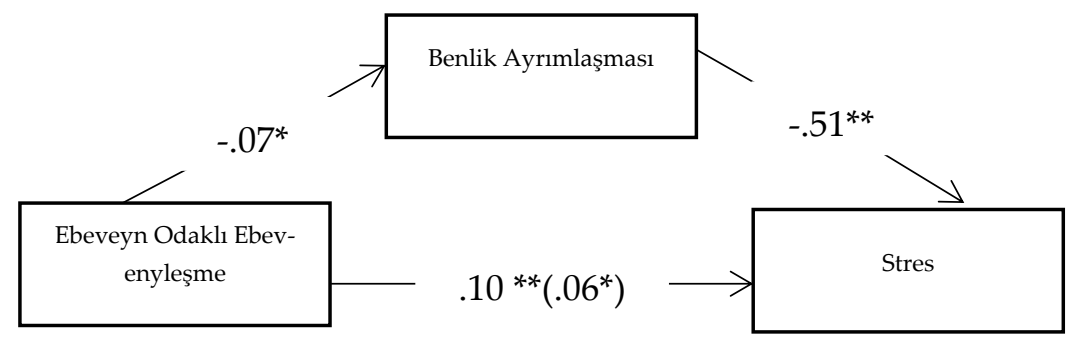

$N=1197,{ }^{* *} p<.01 * p<.05$

Şekil 3. Benlik Ayrımlaşmasının Ebeveyn Odaklı Ebeveynleşme ile Stres Arasındaki Aracı Rolüne Ait Beta Katsayıları

Şekil 3'de görüldügü gibi, benlik ayrımlaşmasının aracılık rolünün incelenmesi için ilk olarak, ebeveyn odaklı ebeveynleşme ile stres arasındaki doğrudan ilişkinin anlamlı olduğu belirlenmiştir $(\beta=10, p<.01)$. İkinci aşamada ebeveyn odaklı ebeveynleşme ve benlik ayrımlaşması $(\beta=-.07$, $\mathrm{p}<.05)$, benlik ayrımlaşmasından strese giden yolun anlamlı olduğu görülmektedir $(\beta=-.51, p<.01)$. Son olarak, benlik ayrımlaşmasının aracilık rolü test edilmiş ve ebeveyn odaklı ebeveynleşme ile stres arasındaki yol katsayısında 4 puanlık anlamlı düşüş görülmektedir $(\beta=.06, p<.05)$. Bu kapsamda ebeveyn odaklı ebeveynleşme ile kaygı arasındaki ilişkide benlik ayrımlaşmasının kısmi aracılık rolü üstlendiği belirlenmiştir. Kısmi aracılık etkisinin anlamlılığını değerlendirmek amacıyla Sobel testi yapılmıştır. Sobel testi sonucunda yol analizindeki değişimin anlamlı olduğu görülmüştür (Sobel Z=2.48; $\mathrm{P}<.05$ ).

Kardeş odaklı ebeveynleşme ile depresyon, benlik ayrımlaşması arasındaki doğrudan ve dolaylı ilişkiler Şekil-4' de yer almaktadır. 


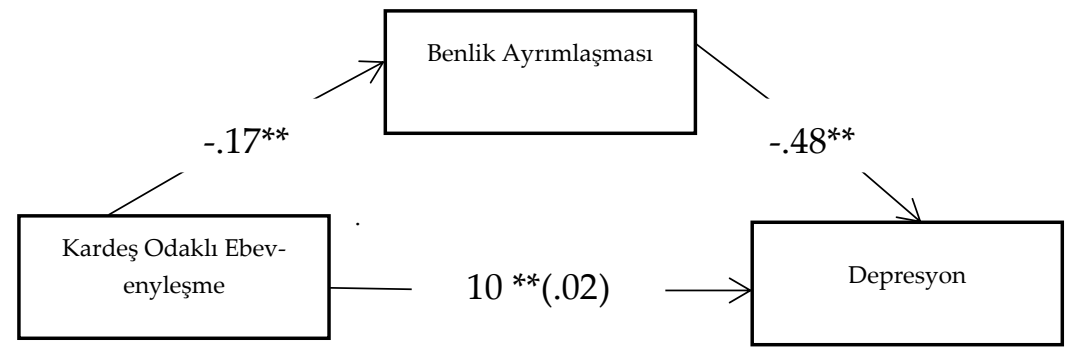

$N=1197,{ }^{* *} p<.01 * p<.05$

Şekil 4. Benlik Ayrımlaşmasının Kardeş Odaklı Ebeveynleşme ile Depresyon Arasındaki Aracı Rollerine Ait Beta Katsayıları

Şekil 4'de görüldüğü gibi, benlik ayrımlaşmasının aracılık rolünün incelenmesi için ilk olarak, kardeş odaklı ebeveynleşme ile depresyon arasındaki doğrudan ilişkinin anlamlı olduğu belirlenmiştir $(\beta=10, p<.01)$. İkinci aşamada kardeş odaklı ebeveynleşmeden benlik ayrımlaşmasına $(\beta=-.17, \mathrm{p}<.05)$ ve benlik ayrımlaşmasından depresyona giden yolların anlamlı olduğu gözlenmiştir $(\beta=-.48, \quad \mathrm{p}<.01)$. Son olarak, benlik ayrımlaşmasının aracilık rolü test edilmiş ve kardeş odaklı ebeveynleşme ile depresyon arasındaki ilişkinin anlamsızlaştığı sonucu elde edilmiştir $(\beta=.02, p>.05)$. Bu kapsamda kardeş odaklı ebeveynleşme ile depresyon arasındaki ilişkide benlik ayrımlaşmasının tam aracılık rolü üstlendiği belirlenmiştir.

Kardeş odaklı ebeveynleşme ile kaygı, benlik ayrımlaşması arasındaki doğrudan ve dolaylı ilişkiler Şekil-5'de yer almaktadır.

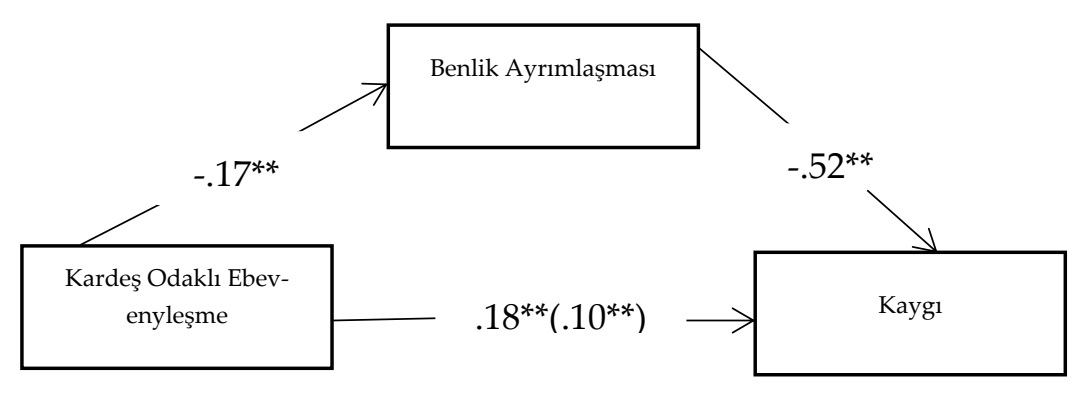

$N=1197,{ }^{* *} p<.01{ }^{*} p<.05$

Şekil 5. Benlik Ayrımlaşmasının Kardeş Odaklı Ebeveynleşme ile Kaygı Arasindaki Aracı Rollerine Ait Beta Katsayıları 
Şekil 5'de görüldügü gibi, benlik ayrımlaşmasının aracılık rolünün incelenmesi için ilk olarak, kardeş odaklı ebeveynleşme ile kaygı arasındaki doğrudan ilişkinin anlamlı olduğu belirlenmiştir $(\beta=.18, p<.01)$. İkinci aşamada kardeş odaklı ebeveynleşme ve benlik ayrımlaşması $(\beta=-.17$, $\mathrm{p}<.01)$, benlik ayrımlaşmasından kaygıya giden yolun anlamlı olduğu görülmektedir $(\beta=-.52, p<.01)$. Son olarak, benlik ayrımlaşmasının aracılık rolü test edilmiş ve kardeş odaklı ebeveynleşme ile kaygı arasındaki yol katsayısında 8 puanlık anlamlı düşüş görülmektedir $(\beta=.10, \mathrm{p}<.01)$. Bu kapsamda kardeş odaklı ebeveynleşme ile kaygı arasındaki ilişkide benlik ayrımlaşmasının kısmi aracılık rolü üstlendiği belirlenmiştir. Kısmi aracılık etkisinin anlamlılığını değerlendirmek amacıyla Sobel testi yapılmıştır. Sobel testi sonucunda yol analizindeki değişimin anlamlı olduğu görülmüştür (Sobel Z=5.88; $\mathrm{P}<.01$ ).

Kardeş odaklı ebeveynleşme ile stres, benlik ayrımlaşması arasındaki doğrudan ve dolaylı ilişkiler Şekil-6’da yer almaktadır.

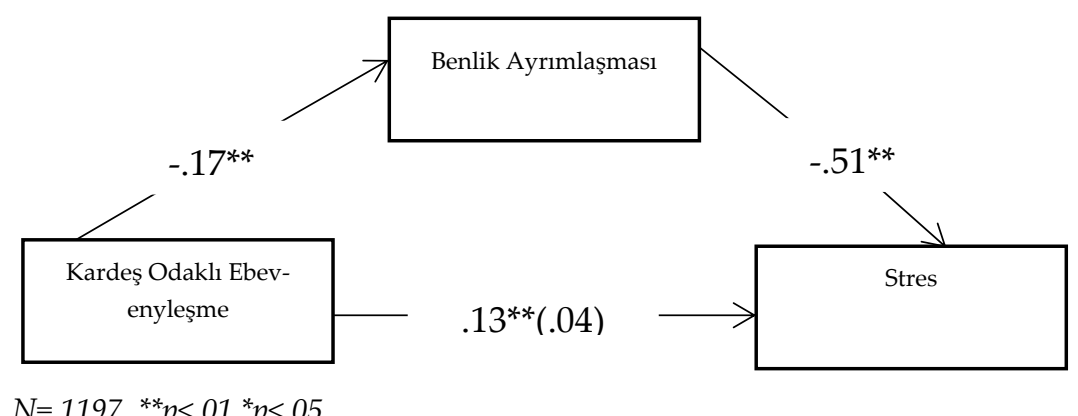

Şekil 6. Benlik Ayrımlaşmasının Kardeş Odaklı Ebeveynleşme ile Stres Arasındaki Aracı Rollerine Ait Beta Katsayılar

Şekil 6'da görüldüğü gibi, benlik ayrımlaşmasının aracılık rolünün incelenmesi için ilk olarak, kardeş odaklı ebeveynleşme ile stres arasındaki doğrudan ilişkinin anlamlı olduğu belirlenmiştir $(\beta=13, p<.01)$. İkinci aşamada kardeş odaklı ebeveynleşmeden benlik ayrımlaşmasına $(\beta=-.17$, $\mathrm{p}<.01)$ ve benlik ayrımlaşmasından strese giden yolların anlamlı olduğu gözlenmiştir $(\beta=-.51, p<.01)$. Son olarak, benlik ayrımlaşmasının aracılık rolü test edilmiş ve kardeş odaklı ebeveynleşme ile stres arasındaki ilişkinin anlamsızlaştığı sonucu elde edilmiştir $(\beta=.04, p>.05)$. Bu kapsamda 
kardeş odaklı ebeveynleşme ile stres arasındaki ilişkide benlik ayrımlaşmasının tam aracılık rolü üstlendiği belirlenmiştir.

Ebeveynleşmeden algılanan yarar ile depresyon, benlik ayrımlaşması arasındaki doğrudan ve dolaylı ilişkiler Şekil-7' de yer almaktadır.

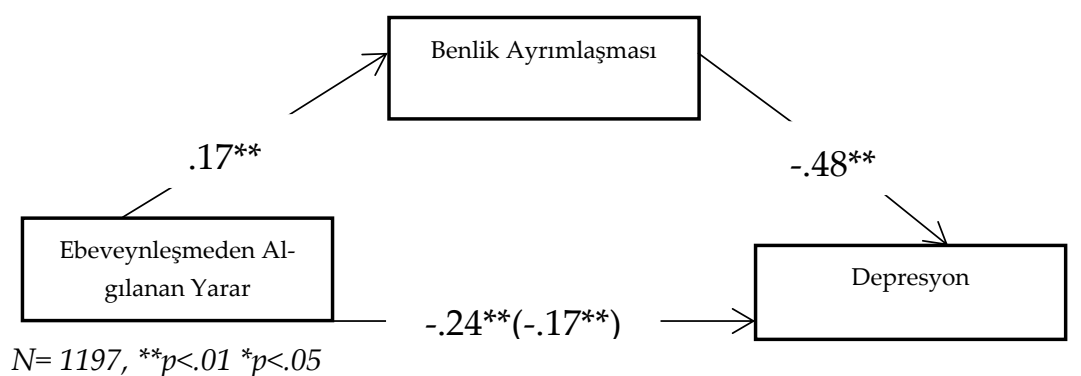

Şekil 7. Benlik Ayrımlaşmasının Ebeveynleşmeden Algılanan Yarar ile Depresyon Arasındaki Aracı Rollerine Ait Beta Katsayıları

Şekil 7'de görüldügü gibi, benlik ayrımlaşmasının aracılık rolünün incelenmesi için ilk olarak, ebeveynleşmeden algılanan yarar ile depresyon arasındaki doğrudan ilişkinin anlamlı olduğu belirlenmiştir $(\beta=-.24$, $\mathrm{p}<.01)$. İkinci aşamada ebeveynleşmeden algilanan yarardan benlik ayrımlaşmasına $(\beta=.17, \mathrm{p}<.01)$ ve benlik ayrımlaşmasından depresyona giden yolların anlamlı olduğu görülmektedir $(\beta=-.48, \mathrm{p}<.01)$. Son olarak, benlik ayrımlaşmasının aracilık rolü test edilmiş ve ebeveynleşmeden algilanan yarar ile depresyon arasındaki yol katsayısında 7 puanlık anlamlı düşüş görülmüştür $(\beta=-.17, \mathrm{p}<.01)$. Bu kapsamda ebeveynleşmeden algılanan yarar ile depresyon arasındaki ilişkide benlik ayrımlaşmasının kısmi aracılık rolü üstlendiği belirlenmiştir. Kısmi aracılık etkisinin anlamlılı̆̆ını değerlendirmek amacıyla Sobel testi yapılmıştır. Sobel testi sonucunda yol analizindeki değişimin anlamlı olduğu görülmüştür (Sobel $\mathrm{Z}=-5.74 ; \mathrm{P}<.01)$.

Ebeveynleşmeden algılanan yarar ile kaygı, benlik ayrımlaşması arasındaki doğrudan ve dolaylı ilişkiler Şekil-8'de yer almaktadır.

Şekil 8'de görüldügü gibi, benlik ayrımlaşmasının aracılık rolünün incelenmesi için ilk olarak, ebeveynleşmeden algılanan yarar ile kaygı arasındaki doğrudan ilişkinin anlamlı olduğu belirlenmiştir $(\beta=-.16$ $\mathrm{p}<.01)$. 


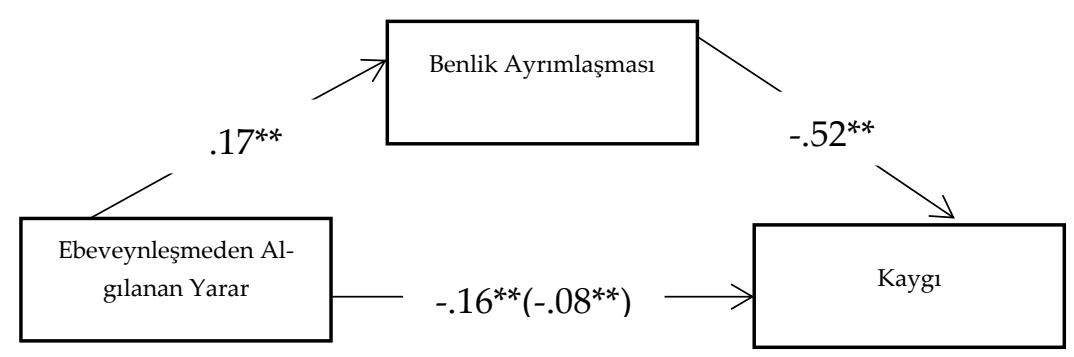

$N=1197,{ }^{* *} p<.01{ }^{*} p<.05$

Şekil 8. Benlik Ayrımlaşmasının Ebeveynleşmeden Algılanan Yarar ile Kaygı Arasındaki Aracı Rollerine Ait Beta Katsayıları

İkinci aşamada ebeveynleşmeden algılanan yarardan benlik ayrımlaşmasına $(\beta=.17, \mathrm{p}<.01)$ ve benlik ayrımlaşmasından kaygıya giden yolların anlamlı olduğu görülmektedir $(\beta=-.52, \mathrm{p}<.01)$. Son olarak, benlik ayrımlaşmasının aracılık rolü test edilmiş ve ebeveynleşmeden algılanan yarar ile kaygı arasındaki yol katsayısında 8 puanlık anlamlı düşüş görülmüştür $(\beta=-.08, p$ <.01). Bu kapsamda ebeveynleşmeden algilanan yarar ile kaygı arasındaki ilişkide benlik ayrımlaşmasının kısmi aracılık rolü üstlendiği belirlenmiştir. Kısmi aracılık etkisinin anlamlılığını değerlendirmek amacıyla Sobel testi yapılmıştır. Sobel testi sonucunda yol analizindeki değişimin anlamlı olduğu görülmüştür (Sobel $Z=-5.78 ; P<.01$ ).

Ebeveynleşmeden algılanan yarar ile stres, benlik ayrımlaşması arasındaki doğrudan ve dolaylı ilişkiler Şekil-9'de yer almaktadır.

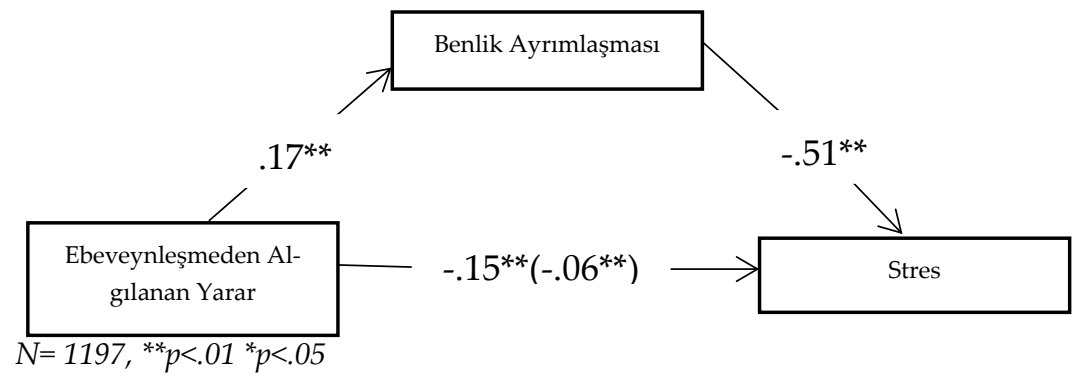

Şekil 9. Benlik Ayrumlaşmasının Ebeveynleşmeden Algılanan Yarar ile Stres Arasindaki Aracı Rollerine Ait Beta Katsayıları

Şekil 9'da görüldüğü gibi, benlik ayrımlaşmasının aracılık rolünün incelenmesi için ilk olarak, ebeveynleşmeden algılanan yarar ile stres 
arasındaki doğrudan ilişkinin anlamlı olduğu belirlenmiştir $(\beta=-.15$ $\mathrm{p}<.01)$. İkinci aşamada ebeveynleşmeden algılanan yarardan benlik ayrımlaşmasına $(\beta=.17, \mathrm{p}<.01)$ ve benlik ayrımlaşmasından strese giden yolların anlamlı olduğu görülmektedir $(\beta=-.51, \mathrm{p}<.01)$. Son olarak, benlik ayrımlaşmasının aracılık rolü test edilmiş ve ebeveynleşmeden algılanan yarar ile stres arasındaki yol katsayısında 9 puanlık anlamlı düşüş görülmüştür $(\beta=-.06, p<.01)$. Bu kapsamda ebeveynleşmeden algılanan yarar ile stres arasındaki ilişkide benlik ayrımlaşmasının kısmi aracılık rolü üstlendiği belirlenmiştir. Kısmi aracılık etkisinin anlamlılığını değerlendirmek amacıyla Sobel testi yapılmıştır. Sobel testi sonucunda yol analizindeki değişimin anlamlı olduğu görülmüştür (Sobel $\mathrm{Z}=-5.78 ; \mathrm{P}<.01$ ).

\section{Tartışma ve Sonuç}

Ebeveyn odakl ebeveynleşme ile depresyon, kaygi, stres arasındaki benlik ayrımlaşmasının aracılık rolüne ilişkin bulguların tartışılması: Araştırmadan elde edilen korelasyon bulgularına göre ebeveyn odaklı ebeveynleşme ile kaygı ve stres arasında pozitif yönde anlamlı ilişkiler elde edilmiştir. Ebeveyn odaklı ebeveynleşme ile depresyon arasındaki ilişkiyi inceleyen çalışmalarda farklı bulgulara rastlanmaktadır. Yapılan çalışmalarda özel gereksinimli kardeşi olan bireyler ve kadınların ebeveynlerine yönelik ebeveynleşmeleri ile depresyon, kaygı ve stres arasında anlamlı ilişkiler bulunmuştur (Tomeny, Barry, Fair ve Riley, 2017; Köyden ve Uluç, 2018). Bununla birlikte sağlıklı kardeşe sahip bireyler ve erkeklerin ise depresyon düzeyleri ile ebeveynlere yönelik ebeveynleşme arasında anlamlı ilişki bulunmamıştır (Arıkan Çolak, 2019; Yıldırım, 2016). Kadınların ebeveynlerine ve diğer aile üyelerine sağladıkları desteklerden dolayı daha fazla etkilenmeleri ile ailede kronik rahatsızlıkların olmasının depresyon riskini arttırdığı alan yazında rastlanan bulgulardan yola çıarak söylenebilir (Akün, 2017; Gilford ve Reynolds, 2011).

Elde edilen diğer bulguya göre, benlik ayrımlaşması ile ebeveyn odaklı ebeveynleşme arasında negatif yönde anlamlı bir ilişki bulunmuştur. Ulaşılan alan yazında ebeveyn odaklı ebeveynleşme ile benlik ayrımlaşması arasındaki ilişkiyi inceleyen araştırmaya rastlanmamıştır. Ancak farklı̈ örneklemlerde ebeveynleşme düzeyi ile benlik ayrımlaşması arasındaki iliş- 
kiyi inceleyen çalışmalarda ebeveynleşme ile benlik ayrımlaşması arasinda negatif yönde anlamlı ilişkiler bulunmuştur (Lee ve Kim, 2019; Jankowski, Hooper, Sandage ve Hannah, 2013). Buradan hareketle benliğin ayrımlaşması düzeyi arttıkça bireylerin ebeveynleri ile kurdukları ebeveyne yönelik ebeveynleşme gibi işlevsel olmayan ilişki örüntülerinin azalacağ 1 söylenebilir.

Bir diğer bulguya göre, benlik ayrımlaşması ile depresyon, kaygı ve stres arasında negatif yönde anlamlı ilişkiler bulunmuştur. Sohrabi, Asadi, Habibollahzade ve PanaAli (2013), benlik ayrımlaşması ile depresyon ve kaygı arasında negatif yönde anlamlı ilişkiler olduğunu belirtmişlerdir. Ayrıca farklı yaş gruplarıyla yapılan çalışmalar benlik ayrımlaşması ile sürekli kaygı (Işık ve Bulduk, 2014; Rodríguez-González ve Józefczyk, 2018) evli bireylerle yapılan bir başka çalışma da ise depresyon, kaygı ve stres ile arasında negatif yönde anlamlı ilişkiler bulunmuştur (Polat ve İlhan, 2018). Son olarak bireylerin benlik ayrımlaşması azaldıkça algılanan stres düzeyinin arttığı saptanmıştır (Murray, Harry Dainels ve Murray, 2006). Araştırmanın bu sonucundan yola çıarak benlik ayrımlaşması düzeyi arttıkça bireylerin aile içerisinde yaşanan duygusal krizlerden daha az etkilenebilecekleri ve bu gibi durumlarda daha düşük düzeylerde depresyon, kaygı ve stres yaşayabilecekleri söylenebilir.

Son olarak, ebeveyn odaklı ebeveynleşme ile depresyon arasında anlamlı bir ilişki olmaması sebebiyle benlik ayrımlaşmasının aracı rolü aranmamıştır. Ebeveyn odaklı ebeveynleşme ile kaygı ve stres arasında ise benlik ayrımlaşmasının kısmi aracılık rolü üstlendiği belirlenmiştir. Ebeveynleşmiş çocuğun yerine getirdiği (ebeveynler arasında arabuluculuk yapma, ebeveynlerine duygusal destek sağlama, ailede önemli kararların alınmasında rol oynama gibi ilişki örüntüleri) yetişkinler için bile çoğu zaman kaygı ve stres uyandırmaktadır. Dolayısıyla bu rol ve sorumlulukların çocuklar tarafından yerine getirildiğinde kaygı ve stres uyandırmasının beklenen bir sonuç olduğu söylenebilir. Alan yazın incelendiğinde ebeveynleşme ile depresyon, kaygı, stres arasında benlik ayrımlaşmasının aracı rolünü inceleyen çok fazla çalışma bulunmamakla birlikte, var olan araştırmalarda benlik ayrımlaşmasının aracılık rolüne ilişkin farklı bulgular yer almaktadır. Lee ve Kim (2019) ebeveyleşme yaşantıları ile depresyon ve kaygı arasında benlik ayrımlaşmasının çok kültürlü ailelerden gelen çocuklarda tam aracılık etkisi, tek kültürlü aileden gelen çocuklarda 
ise kısmi aracılık etkisi olduğunu belirtirken; Jankovski, Hooper, Sandage ve Hannah (2013) ebeveynleşme ile depresyon arasında benlik ayrımlaşmasının aracılık etkisini anlamlı olmadığını rapor etmişlerdir. RodriguezGonzalez vd., 2018), stres ile fiziksel ve psikolojik sağlık ilişkisinde; Sandage ve Jankowski (2010), affetme eğilimi ile ruhsal dengesizlik, akıl sağlığı belirtileri ve psikolojik iyi oluş arasındaki ilişkilerde benlik ayrımlaşmasının aracılık rolü olduğunu rapor etmişlerdir. Anne-babaya yönelik ebeveynleşen bireyler ebeveynleriyle koalisyonlar kurmakta, ebeveynlerinin sırlarını paylaşmakta, çatışmalarda hakem rolü üstlenmekte ya da ebeveynlerinin eşleriyle paylaşmak istedikleri sıkıntılarını paylaşmaktadırlar (Perrin, Ehrenberg ve Hunter, 2013). Benlik ayrımlaşmasının kısmi aracı rol oynaması ebeveynleşen bireylerin ruh sağlığı üzerinde güçlendirici etkisi olduğunu destekler niteliktedir ancak bu ilişkide farklı mekanizmalarında rol oynadığı göz önünde bulundurulmalıdır.

Kardeş odaklı ebeveynleşme ile depresyon, kaygi, stres arasındaki ilişkide benlik ayrımlaşmasının aracılık rolüne ilişkin bulguların tartışılması:Araştırmadan elde edilen korelasyon bulgularına göre kardeş odaklı ebeveynleşme ile depresyon, kayg1 ve stres arasında pozitif yönde anlamlı ilişkiler elde edilmiştir. Kardeş odaklı ebeveynleşme ile depresyon, kaygı, stres arasındaki ilişkiyi ele alan çalışmalar incelendiğinde farklı bulgulara rastlanmaktadır. Köyden ve Uluç (2018) kadınların kardeş odaklı ebeveynleşme düzeyleri ile kaygı ve depresyon düzeyleri arasında pozitif yönde anlamlı ilişkiler bulurken; erkeklerin kardeş odaklı ebeveynleşme düzeyleri ile yalnızca kaygı arasında pozitif yönde anlamlı ilişki bulmuştur. Yıldırım (2016) tarafından yapılan bir başka araştırmada ise ne erkeklerin ne de kadınların kardeş odaklı ebeveynleşme düzeyi ile depresyon arasında anlamlı bir ilişki olmadığı görülmüştür. Arıkan Çolak (2019), ebeveyn odaklı ebeveynleşme de olduğu gibi sağlıklı kardeşe sahip bireylerin kardeşe yönelik ebeveynleşme düzeyleri ile depresyon ve kaygı düzeyleri arasında anlamlı bir ilişki olmadığını; özel gereksinimli kardeşe sahip bireylerde ise kardeş odaklı ebeveynleşme ile depresyon ve kayg1 arasında pozitif yönlü anlamlı ilişkiler olduğunu ifade etmiştir. Fair, Tomeny ve Barry (2014), kardeş odaklı ebeveynleşme ile depresyon, kaygı, stres arasında anlamlı ilişki olmadığını bildirmişlerdir. Dolayısıyla, kar- 
deşe yönelik ebeveynleşme ile depresyon, kaygı ve stres arasındaki ilişkiler çeşitli araştırmalarda farklılık gösterdiği görülmektedir. Fair, Tomeny, Riley ve Barry (2014), yaptıkları bir başka çalışma da kardeş odaklı ebeveynleşmenin kardeşler arasındaki ilişkiyi geliştirebileceğini ifade etmişlerdir. Bireylerin kardeşlerinin öz bakımlarını yapmalarına yardımcı olmaları, kardeşlerinin ödevlerine yardım etmeleri, duygusal anlamda kardeşlerine destek sağlamaları kaliteli kardeş ilişkilerinin geliştirilmesinde önemli bir işlev göstermektedir. Dolayısıyla kardeş odaklı ebeveynleşen bireylerin yaşayacakları depresyon, kaygı ve stres düzeyinin kardeşleri ile kurdukları ilişkinin kalitesine bağlı olarak farklılık göstereceği söylenebilir.

Elde edilen diğer bulguya göre, benlik ayrımlaşması ile kardeş odaklı ebeveynleşme arasında negatif yönde anlamlı bir ilişki bulunmuştur. Ulaşılan alan yazında kardeş odaklı ebeveynleşme ile benlik ayrımlaşması arasındaki ilişkiyi inceleyen araştırmaya rastlanmamıştır. Ancak farklı örneklemlerde ebeveynleşme düzeyi ile benlik ayrımlaşması arasındaki ilişkiyi inceleyen çalışmalarda ebeveynleşme ile benlik ayrımlaşması arasında negatif yönde anlamlı ilişkiler bulunmuştur (Lee ve Kim, 2019; Jankowski vd., 2013). Ebeveyn odaklı ebeveynleşmede olduğu gibi ebeveynleşen çocuklar ebeveynleriyle iç içe girebilecekleri gibi eşleri ya da kardeşleri ile de birleşebilirler. Dolayısıyla, bireysellik ve birliktelik arasında denge olan, benliğin ayrımlaşması geliştikçe kardeşleri ile kurulan ilişkilerde(kardeşe yönelik) ebeveynleşme gibi işlevsel olmayan ilişki örüntülerinin de azalacağı söylenebilir.

Son olarak, kardeş odaklı ebeveynleşme ile depresyon ve stres arasında benlik ayrımlaşmasının tam aracı rolü üstlendiğ $\mathrm{i}$; kaygı arasında ise kısmı aracılık rolü üstlendiği belirlenmiştir. Alan yazın incelendiğinde kardeş odaklı ebeveynleşme ile depresyon, kaygı, stres arasında benlik ayrımlaşmasının aracı rolünü inceleyen çok fazla çalışma bulunmamakla birlikte, var olan araştırmalarda benlik ayrımlaşmasının aracılık rolüne ilişkin farklı bulgular yer almaktadır. Lee ve Kim (2019), ebeveyleşme yaşantıları ile depresyon ve kaygı arasında benlik ayrımlaşmasının çok kültürlü ailelerden gelen çocuklarda tam aracılık etkisi, tek kültürlü aileden gelen çocuklarda ise kısmi aracılık etkisi olduğunu belirtirken; Jankovski, Hooper, Sandage ve Hannah (2013), ebeveynleşme ile depresyon arasında benlik ayrımlaşmasının aracılık etkisini anlamlı olmadığını rapor etmişlerdir. 
Rodriguez-Gonzalez vd., (2018), stres ile fiziksel ve psikolojik sağlık ilişkisinde; Sandage ve Jankowski (2010) affetme eğilimi ile ruhsal dengesizlik, akıl sağlığı belirtileri ve psikolojik iyi oluş arasındaki ilişkilerde benlik ayrımlaşmasının aracılık rolü olduğunu rapor etmişlerdir. Benlik ayrımlaşmasının artması kardeşler arasında daha sağlıklı ilişki örüntüleri kurularak depresyon, kaygı ve stres düzeylerinin azaltılmasına yol açabilir. Alan yazında rastlanan çalışmalar ve bu çalışmadan elde edilen bulgular benlik ayrımlaşmasının ruh sağ lı̆̆ üzerinde güçlendirici etkisi olduğunu destekler niteliktedir.

Ebeveynleşmeden algilanan yarar ile depresyon, kaygi, stres arasındaki ilişkide benlik ayrımlaşmasının aracılık rolüne ilişkin bulguların tartışılması: Araştırmadan elde edilen ilk bulgulara göre ebeveynleşmeden algılanan yarar ile depresyon, kaygı ve stres arasında negatif yönde anlamlı ilişkiler elde edilmiştir. Farklı örneklemlerde yapılan çalışmalarda ebeveynleşmeden algılanan yarar ile depresyon (Arıkan Çolak, 2019; Köyden ve Uluç, 2018; Yıldırım, 2016), kaygı (Arıkan Çolak, 2019; Köyden ve Uluç, 2018; Tomeny vd., 2017), stres (Fair vd., 2014; Tomeny vd., 2017) arasinda negatif yönde anlamlı ilişkiler olduğunu ortaya koymuşlardır. Dolayısıyla, elde edilen bulgulardan yola çıarak ebeveynleşen bireylerin ebeveynleşme yaşantılarından algıladıkları yarar arttıkça, aile içerisinde üstlendikleri roller için takdir ve onay gördükçe depresyon, kaygı ve stres düzeylerinin azalacağı söylenebilir.

Çalışmada elde edilen diğer bulguya göre, benlik ayrımlaşması ile ebeveynleşmeden algılanan yarar arasında pozitif yönde anlamlı bir ilişki elde edilmiştir. Ulaşılan alan yazında ebeveynleşmeden algılanan yarar ile benlik ayrımlaşması arasındaki ilişkiyi inceleyen araştırmaya rastlanmamıştır. Ancak farklı örneklemlerde ebeveynleşme düzeyi ile benlik ayrımlaşması arasındaki ilişkiyi inceleyen çalışmalar da ebeveynleşme ile benlik ayrımlaşması arasında pozitif yönde anlamlı ilişkiler bulunmuştur (Lee ve Kim, 2019; Jankowski vd., 2013). Buradan hareketle benliğin ayrımlaşması düzeyi arttıkça bireylerin ebeveynleri ile kurdukları ebeveyne yönelik ebeveynleşme gibi işlevsel olmayan ilişki örüntülerinin azalacağ1 ifade edilebilir. Hem ebeveyn odaklı ebeveynleşme hem kardeş odaklı ebeveynleşme yaşayan bireylerin aile içerisindeki sorunlara daha fazla çe- 
kildikleri; yaş ve gelişim dönemlerine uygun olmayan rol ve sorumlulukları içeren sağlıksız ilişki örüntüleri oluşturdukları söylenebilir. Dolayısıyla, benliğin ayrımlaşması düzeyi arttıkça bireylerin kardeşlerine ve ebeveylerine yönelik kurdukları ebeveynleşme gibi işlevsel olmayan ilişki örüntülerinin azalacağı yönünde bir yorum yapılabilir. Böylece ebeveynleşen bireyin hem ailesinin tekrar sağlıklı bir takım olarak işlediğini hissedeceği hem de aile içerisindeki rolünden daha hoşnut olacağ ifade edilebilir. Buradan yola çıkarak elde edilen bulguların benlik ayrımlaşmasının artmasının ebeveynleşmeden algılanan yararı arttıracağını doğrular niteliktedir.

Son olarak, ebeveynleşmeden algilanan yarar ile depresyon, kaygı ve stres arasında benlik ayrımlaşmasının kısmi aracı rol üstlendiği belirlenmiştir. Alan yazın incelendiğinde ebeveynleşmeden algılanan yarar ile depresyon, kayg1, stres arasında benlik ayrımlaşmasının aracı rolünü inceleyen çok fazla çalışma bulunmamakla birlikte, var olan araştırmalarda benlik ayrımlaşmasının aracılık rolüne ilişkin farklı bulgular yer almaktadır. Lee ve Kim (2019), ebeveyleşme yaşantıları ile depresyon ve kaygı arasında benlik ayrımlaşmasının çok kültürlü ailelerden gelen çocuklarda tam aracılık etkisi, tek kültürlü aileden gelen çocuklarda ise kısmi aracılık etkisi olduğunu belirtirken; Jankovski vd., (2013), ebeveynleşme ile depresyon arasında benlik ayrımlaşmasının aracılık etkisini anlamlı olmadığını rapor etmişlerdir. Rodriguez-Gonzalez vd., (2018), stres ile fiziksel ve psikolojik sağlık ilişkisinde; Sandage ve Jankowski (2010), affetme eğilimi ile ruhsal dengesizlik, akıl sağlığı belirtileri ve psikolojik iyi oluş arasındaki ilişkilerde benlik ayrımlaşmasının aracılık rolü olduğunu rapor etmişlerdir. Benlik ayrımlaşmasının da ebeveynleşmeden algılanan yarar kadar depresyon, kaygı, stres ile ilişkili olmasına karşın tam aracılık etkisinin olmaması, ebeveynleşmeden algılanan yarar ile depresyon, kaygı ve stres arasında başka mekanizmaların rol oynadığını düşündürmektedir. Benlik ayrımlaşması yüksek olan bireyler sağlıklı duygusal mesafe kurabilmektedirler. Böylelikle ebeveynleşme durumunda aile içerisinde duygusal durumlara zorlanımlı bir şekilde tepki vermek yerine olaylara nesnel tepkiler verebilmektedirler. Ebeveynlerine ve kardeşlerine sağladıkları bakım davranışlarını da zorunlu ve yoğun bir şekilde olmaktan ziyade ebeveyn rollerini denedikleri daha 1 lımlı tepkiler olarak sergileyebilirler. 
Buradan hareketle benlik ayrımlaşmasını gerçekleştiren bireylerin ebeveynleşme yaşantılarından daha fazla yarar algıladıkları söylenebilir. Benlik ayrımlaşmasının ebeveynleşmeden algılanan yarar ile depresyon, kaygı ve stres arasında kısmi etkisinin olması bu konudaki kuramları destekler niteliktedir.

Sonuç olarak bireylerin çocukluk döneminde ebeveyne yönelik ebeveynleşme, kardeşe yönelik ebeveynleşme ve ebeveynleşme yaşantılarından algıladıkları yarar yaşadıkları depresyon, kaygı ve stres düzeyini etkilemektedir. Bununla birlikte ebeveynleşen çocukların benlik ayrımlaşma düzeylerinin artması daha düşük depresyon, kaygı ve stres yaşamalarında etkili olduğu ifade edilebilir.

Elde edilen bulgu ve sonuçlar ışığında ortaöğretim kurumlarında özellikle risk gruplarındaki (boşanmış, tek ebeveyne sahip, yoksul aile çocukları, kronik rahatsızlığı olan öğrenciler vb.) belirlenerek bu çocukların üstlendikleri rol ve aile içerisindeki sınırlar birlikte gözden geçirilmelidir. Koruyucu/önleyici PDR hizmetleri kapsamında bu çocuklarla bireysel ve grupla danışma hizmeti sunulabilir. Aile danışmanlığı alanında çalışan uzmanlar genogram gibi aile içerisinde var olan ilişkileri kuşaklar boyunca inceleyen tekniklerle aile üyelerinin rol ve sorumluluklara yönelik farkındalıkları artırılabilir. Bunun yanı sıra ebeveynler ile çocukların arasında bozulan aile içi rollerin yeniden kurulabilmesi amacıyla bireysel görüşmeler yoluyla bireylerin sağlıklı sınırlar oluşturmalarına destek olunabilir. Ayrıca ebeveynleşme kavramıyla ilgili ülkemizde yapılan çalışmalar olumsuz sonuçlara odaklanılmıştır. Ebeveynleşmenin olumlu sonuçları ile ilgili yapılacak çalışmalar ebeveynleşme olgusu hakkında daha sağlıklı değerlendirmeler yapılmasına katkı sağlayacaktır. Son olarak yapılan çalı̧̧ma üniversite öğrencileri ile sınırlı olup farklı yaş grupları ile gerçekleştirilebilir. 
EXTENDED ABSTRACT

\title{
The Investigetion of the Mediating Role of Differentiation of Self in Relationship between Parentification and Depression, Anxiety and Stress
}

\author{
Ali Karataş - Bülent Gündüz \\ MONE-Mersin University
}

According to the System Theory, the family is not only a structure formed by the coming together of individuals, but a more meaningful whole than the coming together of the parts. According to this theory, although all parts of the family interact with each other, the relations of the individuals forming the family with each other also exhibit a unique pattern (Özabac1 and Erkan, 2017). These unique patterns among individuals carry clues about the interaction and communication patterns among family members, as well as family structure and organization (Becvar and Becvar, 2009). In short, subsystems are smaller parts that make up the whole. Each individual in the family creates subsystems in which they acquire different power, hierarchy and skill. The major subsystems are spouse, parent, and sibling subsystems, and these subsystems are best defined by rules and boundaries (Minuchin and Fishman, 1999). Boundaries are rules that determine who participates in a subsystem and how. In other words, they are invisible lines that regulate how and how much subsystems and individuals interact with each other within the family. (Minuchin, 1974).

Although families differ due to their cultural and ethnic backgrounds, Parke and Buriel (1998) state that a coherent, cooperative parent subsystem is critical for a healthy family. This parent subsystem should be in a position of authority over the child, taking responsibility for nurturing, guiding and controlling the child (Madden-Derdich, UlloaEstrada, Updegraff and Leonard, 2002). It is necessary for the parent subsystem to be central, with clear boundaries and flexible for a healthy functioning of the family (Grief, 1996). It has been observed that when the power hierarchy that places parents in a position of authority over their children is broken in families, problems arise that lead the child to assume the functions of spouse and parent subsystems. When the border between parent and 
child is broken, the child's role in the family system becomes unclear, parental-child (Madden-Derdich et al., 2002; Minuchin, 1974) or parentification (Boszormenyi-Nagy et al. Spark, 1973), a situation in which the child takes on duties and responsibilities that are inconsistent with the child's developmental status. Studies have found that parentification has positive and significant relationships with psychological symptoms such as depression, anxiety, stress, hostility, somatization, and psychotism (Derikosis and Wing-siong, 2017; Köyden and Uluç, 2018; Arellano, MierChairez, Tomek and Hooper, 2018).

Lack of clear boundaries between family subsystems can be expressed as the insufficient realization of self-differentiation of individuals. This situation has been found to be closely related to psychological distress and putting aside personal preferences in order to maintain the balance within the family system (Brown, 1999). Differentiation of self is ability to separate the feelings and thoughts of individuals from each other and also it can be defined as the individual's emotional and cognitive differentiation of himself/herself from his/her family of origin. In general, healthy functioning in the family, especially healthy relational functioning, is associated with the degree of self-differentiation (Bowen, 1978). Studies have shown that individuals with low self-differentiation experience higher levels of depression (Hooper and DePuy, 2010; Lee \& Kim, 2019; Rodriguez-Gonzalez et al., 2018), anxiety and stress (Hanımoğlu and Akbaş, 2018; Polat and İlhan, 2018). Problems in the parentification and family system, especially in the family, seem to be related to the violation of boundaries. From this point of view, in this study, it is aimed to examine the role of differentiation of the self, which expresses the ability of the parented individual to establish a balance between individuality and togetherness with family members, in the relationship between parentification and psychological distress.

The data of the research were collected from 1253 students attending various universities in the 2019-2020 academic year. The study group was formed with the participation of 1197 university students, 429 (35.8\%) male and $768(64.2 \%)$ female, between the ages of 18 and 28. The data on the parentification levels of university students were collected with the "Parentification Inventory" adapted by Köyden (2015), and the data on depression, anxiety and stress levels were collected with the "Depression 
Anxiety Stress Scale" adapted by Akın and Çetin (2007), with the mediating role of the self differentiation to be examined. The data on the selfdifferentiation were collected with the "Differentiation of Self Scale" adapted by Iş1k and Bulduk (2015).

Findings from the research show that as parent-focused parentification increases, anxiety and stress increase; self-differentiation decrease. Based on another finding obtained from the study, as the level of parentification towards siblings increases, the level of depression, anxiety and stress increases and the level of self-differentiation decreased. Finally, as the perceived benefit from parentification experiences increased, depression, anxiety and stress levels decreased and the level of self-differentiation increased. When the findings regarding the mediating role were examined, the mediating role of self-differentiation was not examined since the relationship between parent-focused parentification and depression was insignificant. It was determined that self-differentiation played a partial mediating role in the relationship between parent-focused parentification and anxiety and stress. Self-differentiation between sibling-focused parentification and anxiety has partial mediator role and self-differentiation plays fully mediating role in between depression and stress. Finally, it was revealed that self-differentiation plays a partial mediating role between perceived benefit from parentification and depression, anxiety, and stress. As a result, individuals' parentification towards parents, parentification towards siblings and perceived benefits from parentification during childhood affect the level of depression, anxiety and stress they experience. On the other hand, it can be stated that the increase in the level of self-differentiation of the parentified children is effective in experiencing lower depression, anxiety and stress.

\section{Kaynakça/References}

Akın, A. ve Çetin, B. (2007). The depression anxiety and stress scale: The study of validity and reliability. Educational Sciences: Theory \& Practice, 7(1), 260-268.

Akün, E. (2017). Çocukluktaki ebeveynleşme yaşantılarının özellikleri ve birey üzerindeki etkileri. Nesne Psikoloji Dergisi, 5(10), 219-246. 
Aranello, B., Mier-Chairez, J., Tomek, S. and Hooper, L. M. (2018) Parentification and language brokering: An exploratory study of the similarities and differences in their relations to continuous and dichotomous mental health outcomes. Journal of Mental Health Counseling, 40(4), 353-373.

Arıkan Çolak, D. (2019). Özel gereksinimli ve săğlklı kardeşe sahip bireylerde ebeveynleşme olgusu ile ilişkili değişkenlerin incelenmesi. Yüksek Lisans Tezi. Haccetepe Üniversitesi Sosyal Bilimler Enstitüsü, Ankara.

Bayram, N. (2015). Sosyal bilimlerde SPSS ile veri analizi (5. Baskı). Bursa: Ezgi Kitapevi.

Becvar, D. S. and Becvar, R. J. (2009). Family therapy: A systemic integration. Boston: Allyn ve Bacon/Pearson.

Boszormenyi-Nagy, I. and Spark, G. (1973). Invisible loyalties: Reciprocity in intergenerational family therapy. Hagerstown: Harper \& Row.

Bowen, M. (1978). Family therapy in clinical practice. New York: Jason Aronson.

Brown, J. (1999). Bowen family system theory and practice: Illustration and critique. Australian ve New Zealand Journal of Family Therapy, 20(2), 94103.

Derikosiz, E. and Wingsion, A. (2017). Childhood parentification and adulthood depression and anxiety [Öz]. Akademik Canadian Psychological Association Conferencede sunulan bildiri. Toronto. 15 Temmuz 2020 tarihinde https://www.researchgate.net/publication/317784943_Childhood_Parentification_and_Adulthood_Depression_and_Anxiety adresinden erişildi.

Fair, C. E., Tomeny, T. S. and Barry, T. D. (2014). Adult outcomes in typicallydeveloping siblings of individuals with ASD with respect to childhood parentification. International Meeting for Autism Research sunulan bildiri. Mississippi. 15 Temmuz 2020 tarihinde https://www.researchgate.net/publication/275029272_Adult_Outcomes_in_TypicallyDeveloping_Siblings_of_Individuals_with_ASD_with_Respect_to_Childhood_Parentification adresinden erişildi.

Fair, C. E., Tomeny, T. S., Riley, R. and Barry, T. (2014, Kasım). Developmental disabilities: Parentification, support, and siblings. National Association for the Dually Diagnosed sunulan bildiri. Mississippi. 15 Temmuz 2020 tarihinde $h t t p s: / / w w w . r e s e a r c h g a t e . n e t / p u b l i c a t i o n /-269094649 \_D e-$ velopmental_Disabilities_Parentification_Support_and_Siblings adresinden erişildi. 
Gilford, T. T. ve Reynolds, A. (2010). My mother's keeper: The effects of parentification on black female college students. Journal of Black Psychology, 20(10), 1-23.

Greif, G. L. (1996). Treating the changing single parent family: A return to boundaries. Children Today, 24, 19-22.

Hanımoğlu, E. ve Akbaş, T. (2018). Üniversite öğrencilerinde aile fonksiyonları, benliğin ayrımlaşması, algılanan stres, kaygı ve depresyon arasındaki ilişkinin incelenmesi. Çukurova Üniversitesi Sosyal Bilimler Enstitüsü Dergisi, 27(2), 55-69.

Hooper, L. M. (2009). Parentification inventory (Available from L. M. Hooper, Department of Educational Studies in Psychology, Research Methodology, and Counseling, The University of Alabama, Tuscaloosa, AL 35487).

Hooper, L. M. (2017). Parentification and diverse family systems. J. Carlson ve S. B. Dermer. (Ed.). The SAGE Encyclopedia of Marriage, Family, and Couples counseling içinde (p.1228-1231). Thousand Oaks: SAGE Publications, Inc.

Hooper, L. M. and DePuy, V. (2010). Mediating and moderating effects of differentiation of self on depression symptomatology in a rural community sample. The Family Journal, 18(4), 358-368.

Işık, E. ve Bulduk, S. (2015). Psychometric properties of the differentiation of self inventory - revised turkish adults. Journal of Marital and Family Therapy, 41(1), 102-112.

Jankowski, P. J., Hooper, L. M., Sandage, S. J. and Hannah, N. J. (2013). Parentification and mental health symptoms: Mediator effects of perceived unfairness and differentiation of self. Journal of Family Therapy, 35(1), 43- 65.

Karasar, N. (2011). Bilimsel araştırma yöntemleri. Ankara: Nobel Yayınları.

Khafi, T. Y., Yates, T. M. and Luthar, S. S. (2002). Ethnic differences in the developmental significance of parentification. Family Process, 53(2), 267287.

Köyden, D. (2015). Ebeveynleşme olgusunun depresyon, kaygı, öfke ve obsesif inanış biçimleriyle ilişkisinin incelenmesi. Yüksek Lisans Tezi. Haccetepe Üniversitesi Sosyal Bilimler Enstitüsü, Ankara.

Köyden, D. ve Uluç, S. (2018). Ebeveynleşme ile psikolojik belirtiler arasındaki ilişkide cinsiyetin ve ebeveynleşmeden algılanan yararın rolü. Türk Psikoloji Dergisi, 33(81), 28-38. 
Lee, J. S. and Kim, J. M. (2019). Comparison of the effects of children's parentefication on their internalized problems between multicultural and monocultural families: The mediating effects of internalized shame and self-differentiation. Korean Journal of Child Studies, 40(2), 39-56.

Lovibond, P. F. and Lovibond, S. H. (1995). The structure of negative emotional states: comparison of the depression anxiety stress scales (DASS) with the beck depression and anxiety inventories. Behaviour Research and Therapy, 33, 335-342.

Madden-Derdich, D. A., Estrada, A. U., Ubdegraff, K. A. and Leonard, S. A. (2002). The boundary violations scale: An emprical measure of intergenarational boundary violations in families. Journal of Marital and Family Therapy, 28(2), 241-254.

Majestic, C. and Eddington, K. M. (2019). The impact of goal adjustment and caregiver burden on psychological distress among caregivers of cancer patients. Journal of the Psychological, Social and Behavioral Dimensions of Cancer, 28(6), 1293-1300.

Minuchin, S. (1974). Families and family therapy. Cambridge, Harvard University Press.

Minuchin, S. and Fishman, H. C. (1999). Family therapy techniques. Cambridge: Harvard University Press.

Murray, T. L., Harry Daniels, M. and Murray, C. E. (2006). Differentiation of self, perceived stress, and symptom severity among patients with fibromyalgia syndrome. Families, Systems, \& Health, 24(2), 147-159.

Özabacı, N. ve Erkan, Z. (2017). Aile danışmanlığı kuram ve uygulamalara genel bir bakış. Ankara: Öğretimi, Pegem Akademi.

Parke, R. D. and Buriel, R. (1998). Socialization in the family: Ethnic and ecological perspectives. W. Damon ve N. Eisenberg (Ed.). Handbook of child psychology: Social, emotional, and personality development içinde (p.463-552). New York. Wiley.

Perrin, M. B., Ehrenberg, M. F. and Hunter, M. A. (2013). Boundary diffusion, individuation, and adjustment: Comparison of young adults raised in divorced versus intact families. Family Relations, 62(5), 768-782.

Polat, K. M. ve İlhan, T. (2018). Evli bireylerde çift uyumu ve bazı psikolojik belirtilerin benliğin farklılaşması açısından incelenmesi. Türk Psikolojik Danışma ve Rehberlik Dergisi, 8(50), 87-115. 
Rodríguez-González, M. and Jozefczyk, A. (2018 Ekim). Differentiation and psychological health: an exploratory study among spanish and polish women. 9th Conference of the ESFRAt sunulan bildiri. Porto. 15 Temmuz 2020 tarihinde https://www.researchgate.net/publication/326960929_Differentiation_and_Psychological_Health_an_exploratory_study_among_Spanish_and_Polish_women. adresinden erişildi.

Rodríguez-González, M. and Jozefczyk, A. (2018 Ekim). Differentiation and psychological health: an exploratory study among spanish and polish women. 9th Conference of the ESFRAt sunulan bildiri. Porto. 15 Temmuz 2020 tarihinde https://www.researchgate.net/publication1326960929_Differentiation_and_Psychological_Health_an_exploratory_study_among_Spanish_and_Polish_women. adresinden erişildi.

Sandage, S. J. and Jankowski, P. J. (2010). Forgiveness, spiritual instability, mental health symptoms, and well-being: Mediator effects of differentiation of self. Psychology of Religion and Spirituality, 2(3), 168-180.

Skowron, E. A. and Schmitt, T. A. (2003). Assessing interpersonal fusion: Reliability and validity of a new DSI Fusion With Others subscale. Journal of Marital and Family Therapy, 29, 209-222.

Skowron, E., A. and Friedlander, M., L. (1998). The differentiation of self inventory: Development and initial validation. Journal of Counselling Psychology, 45(3), 235-246.

Sohrabi, R., Asadi, M., Habibollahzade, H. and Pana-Ali, A. (2013). Relationship between selfdifferentiation in bowen's family therapy and psychological health. Procedia - Social and Behavioral Sciences, 84, 17731775.

Tomeny, T., Barry, T. D., Fair, E. C. and Riley, R. (2017). Parentification of adult siblings of individuals with autism spectrum disorder. Journal of Child and Family Studies, 26(4), 1056-1067.

Yıldırım, F. (2016). Aile öngörülmezliği ve ebeveynleşmenin üniversite öğrencilerinin depresyon düzeyleri, öfke tarzları ve obsesif inanışlarn üzerindeki etkilerinin incelenmesi. Yüksek Lisans Tezi. Haccetepe Üniversitesi Sosyal Bilimler Enstitüsü, Ankara.

Zencir, T. (2018). Çocuklukta ebeveynleştirilme, evlilik doyumu ve depresyon. Yüksek Lisans Tezi. Haccetepe Üniversitesi Eğitim Bilimleri Enstitüsü, Ankara. 


\section{Citation Information}

Karataş, A. ve Gündüz, B. (2021). Ebeveynleşme ile depresyon, kayg1, stres arasındaki ilişkide benliğin ayrımlaşmasının aracı rolü. OPUS-Uluslararası Toplum Araştırmaları Dergisi, 18(41), 4453-4481. DOI: $10.26466 /$ opus.883816. 